\title{
Dampak Pandemi Covid-19 dan Pembelajaran Daring di Kampung Atas Air Balikpapan
}

\author{
Nurul Kamaliah Umasangaji ${ }^{1}$, Andi Agustang ${ }^{2}$, Arlin Adam ${ }^{3}$,Andi Alim ${ }^{4}$ \\ Universitas Negeri Makassar ${ }^{1,2}$ \\ Universitas Pejuan Republik Indonesia, ${ }^{3,4}$ \\ Email: nurulumasangaji91@gmail.com
}

\begin{abstract}
Abstrak. Covid-19 merupakan pandemic yang menjadikan iklim pendidikan yang berubah di Indonesia secara signifikan, terutama di dunia pendidikan. Pembelajaran anak sekolah berubah drastic yang awalnya tatap muka menjadi dalam jaringan atau yang kita kenal dengan istilah daring. Penelitian ini bertujuan untuk menjelaskan proses pembelajaran daring dan kajian dampak pandemi covid-19. Metode yang digunakan pada penelitian ini yaitu deskriptif kualitatif dengan pengumpulan data menggunakan teknik angket tidak struktur dan studi pustaka. Subjek penelitian berjumlah 6 responden, yaitu 2 guru kelas, 2 orang tua siswa, 2 siswa. Hasil penelitian ini adalah pembelajaran daring di wilayah Kampung di Atasa Air Balikpapan dengan Siswa yang duduk pada bangku SD dengan memanfaatkan aplikasi whatsapp, google classroom, google meet, video youtube, video pembelajaran guru dan zoom meeting. Dampak positif adanya pandemi Covid-19, bagi guru, siswa, dan orang tua mengenal aplikasi - aplikasi pembelajaran. Namun, lebih banyak dampak negatif yang diperoleh, diantaranya guru memiliki tenaga ekstra dalam melayani siswa, pembelajaran tidak sesuai dengan harapan karena banyak kendala di lapangan, tidak maksimalnya sarana prasarana pendukung menjadi kendala utama sehingga pembelajaran tidak efektif dan efisien. Peserta didik tidak konsentrasi, banyak bermain bahkan tidak mengumpulkan tugas karena malas menyelesaikannya. Orangtrua mengeluarkan biaya tambahan dalam hal menyiapkan data kuota atau jaringan internet.
\end{abstract}

Kata Kunci: Dampak Covid-19, Pembelajaran Daring, Kampung Atas Air

\section{PENDAHULUAN}

Sejak Bulan Maret tahun 2020, Corona Virus Disease atau yang dikenal Covid19 yang dikatakan sebagai pandemi melanda Indonesia. Virus corona masih terus menyebar ke seluruh dunia, dengan hampir 39 juta kasus terkonfirmasi di 189 negara dan lebih dari satu juta kasus kematian pada bulan oktober 2020. Amerika Serikat masih menempati posisi pertama dengan jumlah kasus positif dan jumlah kematian tertinggi di dunia, disusul Brasil dan India.

Penularan virus ini masih terus meningkat di banyak wilayah sejak pandemi terjadi, termasuk Indonesia. Mengantisipasi penyebaran Covid-19 dengan melakukan berbagai macam tindakan, mulai dari wajib cuci tangan, wajib menggunakan masker, social and physical distancing. Anjuran untuk melakukan karantina selama pandemi juga dilakukan (Donthu \& Gustafsson, 2020). Tindakan-tindakan tersebut diupayakan pemerintah agar seluruh masyarakat tidak terlibat dalam kerumunan yang dapat 
dengan mudah dalam penyebaran virus ini.

Upaya yang dilakukan untuk memperlambat penyebaran virus corona harus mendorong penguatan ikatan sosial dengan tetap menjaga jarak fisik (Daniel Aldrich). Komunitas yang bertahan dan dapat bangkit setelah bencana adalah mereka yang memiliki jejaring sosial kuat. Sementara itu, orang-orang di komunitas yang paling buruk adalah mereka yang tidak memiliki koneksi sosial kuat dan tidak saling memercayai. Orang-orang seperti itu sering kali menjadi yang pertama hancur karena bencana. Sehingga untuk membentuk suatu jejaring sosial dari semua bencana yang dibutuhkan adalah kuatnya ikatan sosial, sehingga mempercepat keluar dari suatu bencana dalam hal ini pandemi covid -19 .

Pandemi covid-19 berdampak pada fisik, mental, sosial dan kesehatan spiritual semua orang (Poudel \& Subedi, 2020). Pandemi ini membuat masyarakat sering berpikir negatif dan menjadi sangat sensitif mengingat penyebaran virus yang sangat cepat (Li et al., 2020). Kesehatan mental dan fisik dimasa seperti ini harus dijaga dengan baik agar tidak menimbulkan dampak negatif yang lebih besar (Torales et al., 2020). Dampak pendemi sangat mempengaruhi seluruh lapisan masyarakat baik dari sektor ekonomi, kesehatan maupun pendidikan.

Dengan adanya pandemi ini, maka sekolahpun ditutup secara serentak untuk tidak melaksanakan kegiatan tatap muka. Pelaksaan pembelajaran dilaksanakan dengan sistem Daring dengan acuan Surat Edaran oleh Kementerian Pendidikan dan Kebudayaan tentang Pelaksanaan Kebijakan Pendidikan dalam Masa Darurat Penyebaran Covid-19, satuan pendidikan baik dari tingkat nasional sampai pada tingkat daerah melaksanakan KBM dengan sistem Daring untuk menindaklanjuti edaran menteri untuk tanggap darurat Covid 19. Terdapat model pembelajaran yang digunakan tenaga pengajar pada masa pendemi yaitu dengan penggunaan daring dan pembelajaran kombinasi (Zhafira, Ertika dan Chairiyaton, 2020)

Untuk melancarkan kegiatan pembelajaran saat pandemi ini, Pemerintah mengeluarkan surat Edaran Nomor 4 tahun 2020 tentang pelaksanaan pendidikan dalam

Kegiatan pembelajaran yang dilaksanakan dengan sistem daring yaitu memanfaatkan internet. Pembelajaran daring merupakan program penyelenggaraan kelas pembelajaran dalam jaringan untuk menjangkau kelompok target yang masif dan luas (Bilfaqih \& Qomarudin, 2015, hlm. 1). Kegiatan yang dilaksanakan dengan daring membutuhkan teknologi dan daya dukung lainnya seperti perangkat teknologi dan akses internet.

masa darurat penyebaran Covid-19. Terbitnya edaran tersebut maka pembelajaran daring atau sistem pembelajaran jarak jauh di gunakan pada setiap sendi pendidikan mulai dari tingkat SD, SMP, SMA/SMK bahkan sampai pada Perguruan Tinggi. Daring dilaksanakan dengan memaksimalkan pemanfaatan teknologi serta jaringan internet.

Adanya perubahan sistem pembelajaran dari tatap muka ke daring memiliki dampak pada guru, siswa dan juga orang tua. Guru hanya memfasilitasi dengan 
perpustakaan kelas, modul, buku teks, serta buku pendukung lainnya dan yang terpenting adalah akses internet serta menyediakan keberagaman komputer bagi siswa yang tidak memiliki komputer atau laptop atau perangkat elektronik lainnya ( Tjandra, D.S 2020). Guru dituntut untuk berinovasi dan kreatif pada masa pandemi ini sehingga mempermudah proses pembelajaran dan meningkatkan komunikasi aktif sehingga membangun kerjasama yang baik bersama orangtua dalam pendampingan siswa belajar dirumah. Orangtua memiliki peranan terhadap kegiatan pembelajaran daring saat ini, tanpa bantuan orantua pembelajaran akan terhambat. Siswa saat pelaksanaan KBM Daring 100 \% berada di rumah didampingi orangtua, Guru hanya sebagai fasilitator dalam mempersiapkan kegiatan KBM setiap harinya. Hal serupa dilaksanakan di Kampung di Atas Air dimana melaksanakan kegiatan daring secara full sehingga dalam pelaksanaanya tidak berjalan maksimal. Berbagai jenis aplikasi digunakan dalam kegiatan daring tingkat SD diantaranya Google Meet, Class Room, Zoom Meeting, Whats App, Video Youtube sampai pada Video Pembelajaran yang dibuat oleh guru untuk mengsiasati KBM daring tersebut.

\section{METODE PENELITIAN}

Metode deskriptif kualitatif digunakan pada penenlitian ini. Penggunaan metode ini mendeskripsikan serta merincikan tentang gejala sosial (Agustang, 2011). Teknik pengumpulan data menggunakan teknik angket (Andi Agustang, 2015) data primer dan studi pustaka menjadi data sekunder. angket dilakukan melalui Google foam dengan beberapa pertanyaan yang tidak terstruktur yang hanya memuat inti permasalahan tentang proses pembelajaran daring serta dampak yang dirasakan selama pandemi Covid-19 guna mendukung upaya pemerintah untuk mencegah penyebaran Covid-19. Penelitian ini masuk dalam kategori mini riset dengan melakukan wawancara terhadap 6 responden, yaitu 2 orang tua siswa, 2 orang siswa, serta 2 orang guru.

Data responden akan diberi inisial KA1 - KA6 untuk menjaga kerahasiaan. Berikut daftar responden dalam penelitian ini.

Tabel 1. Profil Responden

\begin{tabular}{cc}
\hline Inisial & Peran \\
\hline KA1 & Guru Kelas \\
\hline KA 2 & Guru Kelas \\
\hline KA 3 & Orang Tua Siswa \\
\hline KA 4 & Orang Tua Siswa \\
\hline KA 5 & Siswa \\
\hline KA 6 & Siswa \\
\hline
\end{tabular}


SEMINAR NASIONAL HASIL PENELITIAN 2021

"Penguatan Riset, Inovasi, dan Kreativitas Peneliti di Era Pandemi Covid-19"

ISBN: 978-623-387-014-6

\section{HASIL DAN PEMBAHASAN}

Penelitian ini menggunakan teknik wawancara melalui telepon dengan sedikit diolah oleh peneliti agar tersampaikan dengan baik. Tanggapan dari guru, orang tua, dan siswa mengenai pembelajaran daring disekolah adalah sebagai berikut:

\section{Interviewer}

\section{Bagaimana proses pembelajaran daring disekolah?}

KA 1: Banyak yang harus disiapkan mulai bahan pembelajaran, model atau metode pembelajaran, data internet, barang-barang elektronik seperti smartphone dan laptop atau computer, bahkan kami harus melayani siswa 1×24 jam, jika ada siswa yang tidak dilayani maka ada teguran keras dari kepala sekolah bahkan kepala dinas. Kami sebagai guru tidak boleh mematikan HP meskipun waktu malam hari, pelayan tanpa batas.

KA 2: $50 \%$ guru tidak dapat menggunakan teknologi dan mengakses internet, guru yang kesulitan akan dibantu rekan timnya satu grade untuk pelaksanaan daring, bahkan kami turun ke sekolah untuk bersama- sama memberikan pelayanan daring kepada siswa. Sebagian besar dari kami tidak paham memanfaatkan aplikasi seperti google classroom, whatsapp, google Meet ataupun zoom meeting. Kami belum terbiasa pelaksanaan daring sehingga membutuhkan waktu lebih lama dan panjang dalam mempersiapkan daring tersebut, apalagi kami menggunakan aplikasi zoom yang tidak berbayar terkadang materi belum selesai, terputus ditengah jalan, sehingga kebanyakan pembelajaran terputus dan sisanya langsung pemberian tugas.

KA 3: Menurut saya kurang efektif karena anak- anak banyak yang tidak mengerti apa-apa karena materi diberikan hanya dalam bentuk tulisan bukan video jadi anak-anak kurang paham. Sekolah ketemu langsung lebih baik bagi kami, karena kami tidak paham mengajari apalagi membimbing anak kami, kami selaku orangtua tidak paham pembelajaran sekolah, kami saja tidak lulus sekolah zaman dulu waktu SD.

KA 4 : Lebih ribet belum lagi kalau anak tiba-tiba malas. Pembelajaran daging saat ini ada yang mudah dimengerti murid dan ada yang tidak karena seorang murid butuh pemahaman khusus.Daring membuat kami sebagai orangtua sangat kerepotan, kami hanay pedagang pasar dan buruh panggul tidak paham penggunaan perangkat elektronik karena HP kami hanya bisa telepon saja. Pembelian data internet menambah beban untuk kami.

KA 5: Membosankan, karena tidak ketemu teman di kelas.

KA 6: Kurang menyenangkan karena banyak tugas dan waktu mengumpulkan tugasnya cepat.

\section{Dampak apa yang dirasakan selama proses pembelajaran daring disekolah?}

KA 1: Dampak yang terlihat adalah ketidaksipan kami guru untuk menghadapi daring. Pemerintah harusnya memberikan peluang kepada guru untuk mengikuti berbagai pelatihan tentang pemahaman teknologi karena jujur kami sebagai guru SD 
sangat minim pengetahuan tentang IT. Kami terbiasa mengajar berinteraksi langsung dengan siswa, sehingga kami butuh tenaga dan pikiran lebih untuk menghadapi daring diluar mempersiapkan pembelajaran, kami juga mempersiapkan diri untuk belajar pada teman yang lebih paham tentang IT, sehingga mengimbangi KBM. Bahkan waktu kami tersita banyak untuk mendampingi siswa belajara jarak jauh.

KA 2: Dampak yang sangat jelas bagi kami guru adalah kesiapan mental dan sarana prasarana. Kami harus mengikuti seluruh aturan main daring meskipun kami gaptek dalam IT. Kami harus mengorbankan banyak waktu untuk belajar tentang IT untuk mampu menguasai penggunaan aplikasi pembelajaran sehingga berpengaruh pada efektifitas belajar. Kompetensi guru banyak yang masih minim terutama dalam penggunaan perangkat lunak menjadikan kendala utama dalam KBM daring.

KA3: Dampaknya anak-anak banyak yang tidak paham dengan pelajarannya dan anak-anak jadi malas belajar akibat banyak dibantu org tua dalam mengerjakan tugas. Belum lagi banyak fasilitas jika ingin mengerjakan tugas. Meskipun ada beberapa guru yang membolehkan mengerjakan dengan tulis tangan namun beberapa harus mengumpulkan via whatsapp group. Kendala terbesar ketika mati lampu atau data habis, maka kami akan kesulitan berkomunikasi dengan guru sehingga tugas anak kami pada hari tersebut dianggap tidak mengerjakan atau tidak mendapatkan nilai. Kendala yang lain, kami tidak memiliki perangkat pembelajaran lebih, sehingga bergantian menggunakan perangkat untuk belajar. Kami menginginkan untuk kegiatan tatap muka segera terlaksana.

KA4: Dampaknya adalah orang tua yang belajar anaknya jadi santai, orangtua yang stress anaknya yang bahagia. Dulu kami menganggap untuk mengajarkan anak sangat mudah, sehingga menurut kami pekerjaan guru hal yang biasa tetapi semenjak pandemik kami berharap segera tatap muka karena kami tidak memiliki keahlian untuk mengajarkan pelajaran yang bagi kami sangat sulit untuk mengajarkan kepada anak dengan tepat dan benar. Kami cukup untuk mencari uang dalam memenuhi kebutuhan hidup, jangan dibuat repot dengan daring. Kami ingin segera tatap muka. Fasilitas yang tidak mendukung kepada kami, jujur saja banayk kerjaan anak - anak yang tidak di kumpulkan selama daring, kami lebih baik guru datang ke rumah kami untuk mengajari anak kami.

KA5:Dampaknya kami jenuh karena terlalu banyak tugas dengan perintah yang monoton, harusnya ada gambar atau video belajar sehingga kami tidak bosan yang hanya menuliskan teks pada lembar jawaban.

KA6: Dampaknya tidak konsentrasi pada saat belajar, karena pada saat belajar menggunakan HP kami sering membuka game untuk bermain atau video lucu yang ada di youtube disebabkan tidak diketahui oleh guru dan orangtua.

Begitulah proses pembelajaran daring di kampung atas air Balikpapan yang telah dipaparkan oleh 6 responden. Berdasarkan hasil angket tersebut menunjukkan bahwa pembelajaran daring tidak efektif dilaksanakan di kampung atas air Balikpapan bagi siswa sekolah dasar, disebabkan fasilitas pendukung tidak maksimal, warga kampung di atas air rata - rata tidak memiliki pekerjaan yang layak. HP, Laptop 
bahkan computer adalah barang yang mewah dan sangat mahal bagi warga setempat, mereka jangankan membeli perangkat tersebut untuk makan saja mereka sudah sangat luar biasa. Mereka lebih terbiasa dengan tatap muka karena itu bagian yang sangat mungkin mereka lakukan, dengan seluruh keterbatasan yang mereka rasakan dan jalani.

Harapan terbaik adalah kerjasama antara guru dan orang tua siswa agar siswa SD yang berada di kampung atas air Balikpapan mampu mengikuti pembelajaran sesuai dengan pencapaian target kompetensi dan tujuan pembelajaran. Guru memberikan materi dan tugas dengan berbagai metode dan strategi, tidak berpatokan pada aplikasi yang pada umumnya saja, seperti aplikasi whatsapp group atau zoom meeting. Guru bisa saja menggandeng orangtua dengan sistem visit dor to door bagi siswa yang tidak memiliki daya penunjang dalam KBM daring. Solusi terbaik selain daring adalah kunjungan dari rumah ke rumah bagi siswa SD kampung di atas air.

Pemberian waktu dalam pengumpulan tugas mungkin lebih di longgarkan, sehingga siswa tidak merasa tertekan dan terpaksa, mengingat pada masa pandemi ini setiap manusia secara individu harus meningkatkan imun dan menghilangkan stress, sehingga daring dijadikan sebuah solusi pembelajaran bukan menjadi sebuah permasalahan baru di masa pandemi . Namun, hal ini belum berjalan sesuai dengan apa yang diharapkan. Pembelajaran dengan tatap muka lebih memberikan respon yang bagus, karena siswa langsung mendengar penjelasan yang disampaikan oleh guru tanpa masalah seperti susah signal, dan lain sebagainya.

Faktor-faktor yang menciptakan pembelajaran online menyenangkan adalah mampu membangun suatu komunitas belajar, dapat memberikan umpan balik dengan tepat, dapat memanfaatkan teknologi untuk memberikan konten yang tepat (Chakraborty \& Muyia Nafukho, 2014). Pembelajaran daring mengenalkan dunia pendidikan dengan berbagai aplikasi pendukung untuk KBM, akan tetapi aplikasi yang dipakai ini harus diketahui secara rinci cara penggunaannya. Bagi masyarakat yang ekonomi keatas menggunakan fitur aplikasi untuk KBM adalah hal yang biasa, beda dengan anak-anak yang berada di lingkungan kampung di atas air, karena mereka tidak memahami secara benar tentang zoom meeting, class room, google meet dst. Ini yang menjadi tantangan sehingga guru dan pihak sekolah harus memiliki strategi yang tepat sehingga pembelajaran ini tetap berlangsung di masa pandemic.

Dampak negative covid 19 yang terlihat disini, pembelajaran tidak berjalan sesuai dengan harapan karena banyak kendala pembelajaran daring, untuk mencapai target tersebut masih membutuhkan tenaga ekstra. Pendidikan merupakan suatu sistem yang mengembangkan misi cukup luas berhubungan dengan perkembangan fisik, keterampilan, pikiran, perasaan, kemampuan, sosial sampai kepada masalah kepercayaan atau keimanan (Warkintin dan Mulyadi, 2019). Pendidikan yang baik dan efektif bukan hanya Peserta didik yang aktif, tetapi seluruh unsure pendidikan dalam hal ini lingkungan sekolah serta lingkungan rumah terkait erat. Peserta didik tidak aktif dalam umpan balik pembelajaran secara cepat, peserta didik tidak memahami 
materi yang diberikan, jaringan dari kegiatan daring menghambat proses KBM, kurangnya alat komunikasi membuat peserta didik tidak dapat mengumpulkan tugas secara tepat waktu, orang tua karena sebagian besar orangtua yang mengerjakan tugas anak, penjelasan guru terputus ketika signal buruk sehingga materi tidak tersampaikan dengan baik kepada siswa, peserta didik tidak bisa bergabung dalam daring karena kondisi jaringan dan internet.

Pembelajaran daring membutuhkan tenaga ekstra baik siswa, guru maupun orangtua. Daring membutuhkan waktu dalam pemberian pembelajaran dan melayani siswa dari guru, sedangkan orangtua yang awalnya hanya berfokus pada urusan keluarga, sekarang harus memberikan waktu lebih untuk pendampingan anak dalam pembelajaran di rumah. Daring bagian yang dibutuhkan saat ini untuk menyikapi pandemic secara bijak tetapi menimbulkan permasalahan yang acap kali ditemukan dilapanagan, semisalnya penggunaan HP untuk belajar dimana tidak semua keluarga mampu menyiapkan HP pada anak-anaknya untuk daring. Guru harus lebih melayani secara maksimal tanpa batas waktu, kapanpun siswa memperoleh kesulitan guru harus siap untuk pendampingan tanpa mengenal waktu. Sebaliknya orangtua menjadi kerepotan dengan aktivitas daring, karena tidak sedikit orangtua yang harus menyelesaikan tugas dari anak-anak ketika anak-anaknya sedang tidak suka dalam melaksanakan tugas, akhirnya orantua yang menyelesaikan karena tuntutan dari KBM.

\section{KESIMPULAN}

Dampak Positif dalam pembelajaran dengan menggunakan sistem daring yang menjadi topik yang menarik dalam masa pandemi Wabah Covid-19 ini adalah banyak mengetahui tentang aplikasi- aplikasi asing selama ini menjadi familiar dan umum untuk bisa di pelajari. Guru meningkatkan kompetensinya dalam bidang teknologi dan informasi sehingga tidak di sebut guru yang gagal teknologi. Guru bersosialisasi dengan rekan sejawat baik di dalam sekolah maupun diluar sekolah untuk mendapatkan ilmu dan sharing pengalaman pembelajaran daring yang lebih tepat untuk mencapai tujuan KBM. Mengenal aplikasi whatsapp, google classroom, google meet, video youtube, video pembelajaran guru dan zoom meeting yang dulunya tidak digunakan, sekarang menjadi sesuatu yang wajib digunakan dalam pembelajaran.

Dampak positif adanya pandemi Covid-19, siswa dan orang tua mengerti menggunakan teknologi dalam pembelajaran. Siswa dan orangtua mengenal yang dinamakan aplikasi untuk sarana pembelajaran, seperti whatsapp, zoom meeting, google classroom, google meet, video youtube, video pembelajaran guru dan lain sebagainya. Melalui aplikasi- aplikasi tersebut diharapkan siswa tetap melaksanakan pembelajaran layaknya ketika di sekolah dan orangtua menjadi pendukung utama untuk pendampingan anaknya di rumah dalam penyelesaian tugas. Orangtua lebih memiliki waktu banyak untuk bersama anaknya karena proses daring, apalagi anak SD yang membutuhkan perhatian lebih dari orangtua dalam pembelajaran daring.

Dampak negatif yang dirasakan. Guru memiliki kendala dalam pembelajaran daring karena banayk hal yang disiapkan dalam KBM, mulai dari jaringan internet, 
perangkat pembelajaran, sarana prasarana yang berhubungan dengan daring sehingga dapat dilaksanakan sesuai dengan harapan. Bagi siswa dampak negatifnya adalah siswa cenderung tidak konsentrasi dan memperhatikan apa yang disampaikan oleh guru, pengerjaan tugas yang tidak tepat waktu, siswa lebih banyak bermain dan malas serta berkurangnya perhatian dalam pembelajaran, ini bisa dilihat dari hasil hasil kerja siswa sehingga kendala inilah yang sangat memprihatinkan atas prestasi dan nilai dari siswa tersebut. Dampak negatif bagi orangtua melonjaknya pengeluaran biaya untuk kuota internet, waktu menjadi terbagi dengan aktivitas rutinnya serta orangtua turut serta dalam pengerjaan tugas agar tugas anaknya terpenuhi.

Saran Semua pihak yang terlibat yaitu, guru, peserta didik, dan orang tua siswa memiliki fasilitas yang baik dalam mempersipakan pembelajaran daring. Materi yang disajikan guru kepada siswa lebih variatif dan tidak monoton baik dari pemilihan model pembelajaran, metode pembelajaran, strategi pembelajaran maupun teknik pembelajaran bahkan materi yang disiapkan harus menarik dan memuat materi esssensial dalam kurikulum, singkat, padat dan jelas. Keaktifan serta partisipasi orangtua serta mendukung penuh kepada anaknya, menjadi motivasi bagi anak dalam belajar. Bagi peserta didik wajib menerima kondisi pembelajaran daring dengan baik dan belajar secara efektif dengan memanfaatkan waktu untuk menyelesaikan kegiatan belajar, sehingga memudahkan memahami materi, dan mengumpulkan seluruh tugas tepat waktu.

\section{UCAPAN TERIMA KASIH}

Kepada allah SWT yang telah memberikan kesempatan dan ijinnya sehingga rampungnya artikel ini, Ibunda Tercinta berkat Doanya, Ayahanda Tersayang karena memotivasi serta keluarga tercinta. Terkhusus Prof. Andi Agustang selaku Kaprodi S3 Sosiologi, Seluruh Pengajar di S3 Prodi Sosiologi UNM Makassar serta Rekan Seangkatan di S3 Prodi Sosiologi angkatan 2020 UNM Makassar.

\section{DAFTAR PUSTAKA}

Agustang, A. (2011). Pendekatan Penelitian Kualitatif dan Kuantitatif Suatu Tinjauan Kritis. In Makassar: Andira Publisher. Andira Publisher.

Andi Agustang. (2015). Dasar-Dasar Filsafat Penelitian Untuk Pengembangan Ilmu (I. I. Idrus (ed.); pertama). CV Multi Global.

Chakraborty, M., \& Muyia Nafukho, F. (2014). Strengthening student engagement: What do students want in online courses? European Journal of Training and Development, 38(9), 782-802. https://doi.org/10.1108/EJTD-11-2013-0123

Daniel, Aldrich. (2020).Pandangan Para Ahli soal Social Distancing dan Physical Distancing, Artikel

Li, S., Wang, Y., Xue, J., Zhao, N., \& Zhu, T. (2020). The impact of covid-19 epidemic declaration on psychological consequences: A study on active weibo users. International Journal of Environmental Research and Public Health, 17(6). https://doi.org/10.3390/ijerph17062032 
Poudel, K., \& Subedi, P. (2020). Impact of COVID-19 pandemic on socioeconomic and mental health aspects in Nepal. International Journal of Social Psychiatry, 66(8),748-755. https://doi.org/10.1177/0020764020942247

Warkintin, W., \& Mulyadi, Y. B. (2019). Pengembangan Bahan Ajar Berbasis CD Interaktif Power Point Untuk Meningkatkan Hasil Belajar Siswa. Scholaria: Jurnal Pendidikan Dan Kebudayaan, 9(1), 82-92.

Zhafira, N. H., Ertika, Y., \& Chairiyaton, C. (2020). Persepsi Mahasiswa Terhadap Perkuliahan Daring Sebagai Sarana Pembelajaran. Jurnal Bisnis Dan Kajian Strategi Manajemen, 4(1).

Agustang, A. (1999). INTERAKSI SOSIAL DAN PERUBAHAN STRUKTUR KOMUNITAS. Universitas Padjadjaran Bandung.

Agustang, A. (2009). SIMBOLIKHAJl: Studi Deskriptif Analitik pada Orang Bugis. AlQalam, 15(2), 317-334.

Agustang, A. (2014). LIFE BEHAVIOR OF SOCIETY, FIVE CASES ON FAMILY OF DIABETES MELLITUS PATIENTS IN MAKASSAR. International Journal of Academic Research, 6(1).

Agustang, A. (2021). Teknologi Partisipasi Metode Fasilitasi Pembuatan Keputusan Partisipatif. OSF Preprints.

Agustang, A., \& Adam, A. (2020). INSTITUTIONAL FAILURES IN THE WORLD OF EDUCATION IN SCHOOLS FOR CHILDREN VICTIMS OF PARENTS. Asian Journal of Social Sciences \& Humanities, 9(2), 18-26.

Agustang, A., \& Oruh, S. (2021). KESEJAHTERAAN PSIKOLOGIS (studi Pada Dewasa Madya Yang Belum Menikah Di Kota Makassar).

Agustang, A., Saleh, S., Rasyid, R., \& Agustang, A. T. P. (2019). Pengembangan profesionalisme guru SMP Negeri 1 Duampanua Kabupaten Pinrang melalui pelatihan penulisan karya tulis ilmiah. Seminar Nasional Pengabdian Kepada Masyarakat, 2019(2).

Agustang, A., Suardi, S., Putra, A. D. M., \& Oruh, S. (2021). Pemberdayaan Guru Mata Pelajaran Sosiologi Melalui Literasi Digital Berbasis Quick Response Code di Kecamatan Bissappu Kabupaten Bantaeng. Abdi: Jurnal Pengabdian Dan Pemberdayaan Masyarakat, 3(2), 175-188.

Agustang, A. Y. A., Herman, H., Said, M., \& Agustang, A. (2021). Upaya Guru IPS Dalam Meningkatkan Motivasi Belajar Siswa Pada Masa Covid 19 Di SMP. Phinisi Integration Review, 4(1), 144-149.

Ahriani, A., Agustang, A., Adam, A., \& Upe, A. (2020). The Multiple Roles of Women in Poor.

Akbar, H., Oruh, S., \& Agustang, A. (2021). Indeks Prediktif Kejadian Demam Berdarah Dengue (DBD) Berbasis Perilaku Sosial Masyarakat Di Kabupaten Indramayu. Jurnal Kesehatan, 14(2 SE-), 76-82. https://doi.org/10.32763/juke.v14i2.289

Alim, A., Agustang, A., \& Adam, A. (2021). Transformation of Consumption Behavior of the Poor in the Case of Malnutrition: Health Sociology Study with Participatory Approach in Makassar City, Indonesia. Open Access Macedonian Journal of Medical Sciences, 9(E), 598-607. 